\title{
Fight Metaphors in Spain's Presidential Speeches: J.L. Rodríguez Zapatero (2004-2007)
}

\author{
María Josefa Hellín García \\ University of West Georgia \\ mjhellin@westga.edu
}

\begin{abstract}
This article investigates the metaphorical conceptualization of terrorism by president José Luis Rodríguez Zapatero, who came into power soon after the biggest terrorist attack in Spain on March $11^{\text {th }}, 2004$. Specifically, it examines how terrorism is conceptualized via metaphors through the notion of fight, and their conceptual implication in discourse. I will refer to these as Fight Metaphors. The research questions addressed are as follows: 1. What Fight Metaphors are used in the discursive construction of terrorism? 2. How do Fight Metaphors contribute to support Zapatero's anti-terrorism political agenda? I follow a combination of a cognitive and a pragmatic approach from a corpus-based analysis perspective. The cognitive approach is based on Lakoff's Conceptual Metaphor Theory (1993), and the pragmatic one is based on Charteris-Back's Critical Metaphor Analysis (2004). The corpus of investigation comprises 58 Spanish political speeches over a threeyear period (2004-2007). Findings reveal that Fight Metaphors constitute the pivotal node that simultaneously performs various functions at several levels: cognitive, rhetorical, and ideological in order to promote his anti-terrorism political ideology.
\end{abstract}

\section{Introduction}

Terrorism has been a major social issue in Spain for more than forty years. March $11^{\text {th }}, 2004$ (also known as 11-M) is remembered as the most devastating terrorist attack that occurred in Spain, just three days prior to the general presidential election. President José Luis Rodríguez Zapatero is widely believed to have come to power in April 2004 because of his anti-terrorism 
agenda, and his priority can be aptly summarized with the conceptual metaphor: TERRORISM IS A FIGHT. However, in presidential speeches against terrorism, Zapatero uses metaphors that draw heavily from the source domain of fight, and are connotative of violence. I will refer to these as Fight Metaphors. This contrast results in an apparent contradiction of having a propeace political ideology but using language substantially composed of violence. The contradiction raises the question of why Zapatero uses Fight Metaphors when his underlying political ideology is a peaceful one. This article investigates how terrorism is conceptualized through metaphorical expressions related to the notion of fight, and their conceptual implication in discourse. Particularly, the analysis shows how president Zapatero presents terrorism within a conceptual Fight Frame to support his anti-terrorism political agenda. The research questions are as follows: 1. What Fight Metaphors are used in the discursive construction of terrorism? This includes not only the metaphoric conceptualization of the word terrorism in itself, but also other aspects of terrorism. For example, how to solve this conflict, how Spaniards dealt with terrorist attacks, and their fear of living in a country where there are terrorist attacks, among other aspects. 2. How do Fight Metaphors contribute to support Zapatero's anti-terrorism political agenda?

The analysis is based on 58 political speeches of Zapatero over a three-year period (20042007). All speeches are related to terrorism. For the purpose of this investigation, the theoretical and methodological approach undertaken combines two main perspectives: The cognitive approach is based on George Lakoff's Conceptual Metaphor Theory (1993), and the pragmatic approach is based on Jonathan Charteris-Black's Critical Metaphor Analysis (2004). The cognitive approach will help to understand and to interpret the metaphor as a part of human thought, while the pragmatic analysis will help to interpret the context in which the metaphors occur.

This study aims to contribute to the role of metaphor in discourse. Metaphor in discourse has been mostly studied in the English language (Charteris-Black, 2004, 2005; Howe, 1988; Johnson, 2002; Lakoff, 2001, 2003, 2004, 2005; Layton, 2002; Mio, 1996; Musolff, 1998, 2000, 2001, 2003, 2004; Rohrer, 1995; Sandikcioglu, 2000). However, relatively few studies have been done in the Spanish language (Salvador, 1987; Rohrer, 1991; Pujante and Morales, 1996-7; Santa Ana, 1999; Etkin, 1999; Fernández Lagunilla, 1999; Hernández, 2002; Pérez Rull, 2002). Consequently, there is a need to explore how metaphors work in Spanish within the domain of politics. Pujante and Morales (1996-7) attribute the lack of a research tradition in Peninsular Spanish political discourse to an absence of democracy in Spain until recent decades.

After this introduction, a brief background about the historical and geopolitical context of terrorism in Spain will be provided (in Section 2). Next, Section 3 explores the role of metaphor in political discourse where I will refer to some major studies on terrorism. Section 4 presents the corpus and theoretical framework. Section 5 is devoted to the analysis and results of the investigation. Finally, Section 6 closes with a synthesis of the conclusions. 


\section{Historical and geopolitical context: Terrorism in Spain}

This section briefly mentions the historical and geopolitical context in which Fight Metaphors are employed. Since it is not feasible to comprehensively illustrate the entire Spanish political history, this section focuses on the events that are most relevant to the analysis.

Spain has undergone numerous political changes. The establishment of democracy after almost 40 years of Franco's dictatorship has been marked by obstacles. Franco's dictatorship promoted a strong censorship against regionalism. This created widespread discontent and provoked an anti-Castilian sentiment, especially in the Basque Country, which led to the rise of terrorist movements. Franco's death in 1975 brought an end to dictatorship and gave way to the inception of a transition period that ultimately led to Spain becoming a liberal democratic state with the establishment of the constitution in 1978. The dictatorship ended, but terrorism did not. Terrorism has been one of the main concerns of Spain's Government. Since the late 1960s, terrorist attacks started in Spain. Most of these were perpetrated by terrorist groups such as ETA and GRAPO. International groups such as Al-Qaeda also attempted to disrupt democracy with the Madrid train bombing attack on March $11^{\text {th }}, 2004$. This shows that in Spain terrorism is not merely linked to a national threat but also to an international one. With all these terrorist groups combined, more than 1200 victims have been killed in attacks until 2004 (Pulgar Gutiérrez, 2004). 11-M was the deadliest terrorist attack occurred in Spain, which killed 192 people and left around 1600 wounded. 11-M attack came exactly 911 days after "9-11" World Trade Center terrorist attack in New York City, USA. Both attacks were attributed to the terrorist group Al-Qaeda (Pulgar Gutiérrez, 2004). It is contended that this date was specifically chosen to impact Spanish politics. The Spanish president at that time, José María Aznar, backed the US-led invasion of Iraq despite the discontent of the Spanish public who were strongly against it. The 11-M attack took place just three days before the general elections, scheduled for March $14^{\text {th }}, 2004$. In the election, the presiding Spanish government Popular Party (right wing) was unexpectedly defeated by the Socialist Party (left wing), whose candidate José Luis Rodríguez Zapatero became president (until present). It is believed that the general public accredited the attack to the political policies of the previous government. It is thus contended that Zapatero's anti-war and antiterrorism ideology was the deciding factor in his coming into power. This is an important factor to consider while analyzing Zapatero's metaphors related to terrorism. Zapatero's main objective, since the beginning of his presidency, has been to achieve peace with ETA, and to eventually put an end to terrorism in Spain.

\section{Literature review: Metaphor and Politics}

Research, since the 1980s, shows that the use of metaphor in framing political discussion has become a major linguistic device, and a tool used by politicians (Pujante and Morales, 1996-7; Howe, 1988; Fernández Lagunilla, 1999; Lakoff, 2001, 2003, 2005; Pérez Rull, 2002; Mussolf, 2003; Charteris-Black, 2005). Thompson (1996) emphasizes this in his article Politics without metaphor is like a fish without water. Thompson (1996:188) further indicates 
that metaphors help to make the central concepts of politics such as ideology, influence, and power, more tangible and concrete to the general public. Metaphors are capable of restructuring concepts and opinions (Kyratzis, 2001: 64). Hence, they are used for transmitting ideology. Metaphor is thus one of the means for political change (Kyratzis, 2001: 65). González García (1998: 15) indicates that if metaphors were removed from political language, then political language would be devoid of any potential to transfer useful knowledge about our life in society. He affirms that metaphors have an important role in political argumentation since they persuade and may be part of taking political action. Kövecses (2002:62) indicates that "politics in general is rife with conceptual metaphors". Lakoff and Johnson (1980:159) state that metaphors play a central role in constructing social and political reality. Also, metaphor is a convenient and natural way through which political leaders communicate their beliefs, identity, and ideology. Charteris-Black (2005: 198) states that the choice of metaphors used by a politician determines leadership style because "like the choice of clothes by an individual, it is a way of appealing to others to share a virtuous social identity”. Fernández Lagunilla (1999: 69) indicates that metaphor is an indirect verbal strategy that allows the politician to talk about delicate issues at the time that gives $\mathrm{him} / \mathrm{her}$ communicative immunity. She provides some examples of metaphor usage in the rhetoric of some Spanish politicians such as Jose María Aznar, Felipe González, Julio Anguita, and José Borrell.

Metaphors are important in politics because they are used to frame political debate. Politicians use frames when reporting political issues because frames simplify complex information in a way that it becomes more accessible to the general public. Lakoff(2004: XV) argues that frames are mental structures that shape the way we see the world. The speaker transmits certain ideas that reflect his belief system and ideology. Lakoff (2004: 4) further points that the speaker consciously highlights some aspects while omitting others. The ability to frame complex political issues such as war or terrorism is crucial for the politician since they are used to justify measures for or against them. Lakoff $(2001,2003,2005)$ indicates the importance of metaphorical reasoning in framing political events, as the justification of a war or a terrorist attack. For example, Lakoff (2003) analyzed the underlying conceptual system of the frame used by president George Herbert Walker Bush to justify the first Gulf War on moral grounds. Bush outlined in his speech what Lakoff (2003:4) refers to as a "fairy tale structure", where there is a villain, a hero, and a victim that metaphorically symbolizes Iraq/Saddam Hussein, US, and Kuwait respectively. Within the fairy tale structure, Bush justified the need to go to war by using a rescue scenario. This means, US (the hero) rescued Kuwait (the victim) from the cruel immoral hands of the villain (Iraq/Saddam Hussein). Lakoff (2003) pointed out that framing the war as a moral justification was the only way by which Americans would accept the war. Following Lakoff's work, Rohrer (1995) analyzed the analogical reasoning behind the metaphors used by G.W Bush to refer to the Iraqi invasion. Bush mainly used the conceptual metaphor NATION IS A PERSON to describe the Gulf Crisis. Rohrer mentions that president Bush's metaphors were widely accepted by the American public, and this was a decisive factor in gathering support for the 1991 Persian Gulf War. Thus, Bush argued for the Iraq invasion with metaphors that were chosen specifically to gain acceptance and support from the general public. 
Lakoff (2001) analyzed the conceptual system of how the September 11 (2001) attack on the World Trade Center was framed by Bush's administration. He pointed out the power of images and how images may be considered symbols that reflect our identity. He explained that the buildings of the World Trade Center represented the society, people standing and the collapse of the towers represented the killing of people, and The Pentagon represented a vaginal image, which was penetrated from the air by the plane as a missile.

Charteris-Black (2005) analyzed the metaphorical language of different political leaders such as Margaret Thatcher, Tony Blair, and George W. Bush when referring to terrorism. This author (2005: 92) reports how Thatcher describes terrorism as a social problem and refers to it as the fight against terrorism. He (2004: 150) also indicates how Blair shifts in what he refers to as evil before and after September $11^{\text {th }}, 2001$. Before this date, Blair referred to evil as crime, anti-social behavior, racial intolerance, drug abuse, etc. However, today, terrorism is also portrayed as evil:"This mass terrorism is the new evil in our world today. It is perpetrated by fanatics who are utterly indifferent to the sanctity of life and we, the democracies of this world, are going to have to come together and fight it together and eradicate this evil completely from our world" (11 September 2001) (adapted from CharterisBlack, 2005: 150). Charteris-Black (2005: 162) also mentions how Blair conceptualizes terrorism by using personification. Blair portrayed terrorism as an animate entity like malign offspring that is fed by the indecision of the United Nations. He (2005: 174) indicates that George Walker Bush frequently uses personification as a way of making evaluations. In Bush's discourse, terrorists are personified with a strong negative evaluation such as vermin, insects, and parasites. Besides, hunting and animal images were employed early in his speeches to portray terrorists (Charteris-Black, 2005: 182). The device of personification is employed to construct the image of the enemy as dangerous and inhuman in order to later show its destruction. The conceptual metaphor implied is TERRORISTS ARE DANGEROUS ANIMALS. Furthermore, terrorists are also portrayed as animals that can be eliminated, that is, parasites. The conceptual metaphor implied is TERRORISTS ARE PARASITES.

\section{Corpus and theoretical framework}

The corpus data was analyzed using a combination of two approaches: Lakoff's Conceptual Metaphor Theory and Charteris-Black's Critical Metaphor Analysis. The former is a cognitive approach based on the following works: Lakoff and Johnson (1980) and Lakoff (1987). The latter is a pragmatic approach based on Charteris-Black $(2004,2005)$. The cognitive framework will provide the conceptual metaphor that structures the metaphorical system used by Zapatero when he conceptualizes terrorism. The pragmatic approach is based on Discourse Analysis, and it aims to identify mainly the intentions and ideologies underlying language usage (Charteris-Black, 2004:34). He mentions that his method gives insights into the beliefs, attitudes, and feelings of the discourse community in which they are found.

The corpus consists of 58 political speeches related to terrorism from April 2004 to April 2007. This corpus was taken from the official web site of La Moncloa (http://www.lamoncloa.es/default.htm), which provides the official transcription of the speeches. Only the parts of the political speeches that mentioned aspects related to terrorism were selected from 
the corpus. The extracted portions were identified manually. The conceptualization of terrorism includes aspects related to it such as: how to solve the conflict, the consequences of terrorism in the Spanish society, possible solutions that Zapatero provides to end terrorism, how terrorism affects not only citizens of Spain but also citizens of other countries, and how citizens face terrorist attacks.

Conceptual Metaphor Theory was proposed by George Lakoff and Mark Johnson in Metaphors We Live By (1980). This cognitive theory posits that the way we perceive the world is reflected in our thought, which is structured metaphorically. Lakoff and Johnson indicate that the metaphors we use in our daily lives reflect our way of understanding the world. The term conceptual metaphor represents a set of ontological correspondences between two semantic fields or domains. Lakoff (1987:276) indicates that each metaphorical expression has a source domain, a target domain, and a source-to-target mapping. Their theory refers mainly to metaphors in everyday life, and not in politics. However, subsequent research studies show that their cognitive theory is applicable to the study of metaphor in the political discourse.

Critical Metaphor Analysis consists of the following steps: metaphor identification, interpretation, and explanation. Metaphor identification includes the identification of candidate metaphors, which are metaphorical expressions, as well as metaphor keywords, which are the words used metaphorically. Along with this, conceptual metaphors and conceptual keys, which are more general conceptual metaphors, will also be inferred from the metaphorical expressions. The procedure can be exemplified as follows:

Candidate metaphors (la patología del terrorismo, la epidemia del terrorismo) $>$ Metaphor keyword (patología, epidemia) $>$ Source domain $($ Body) $>$ Conceptual metaphors (TERRORISM IS A PATHOLOGY, TERRORISM IS A PLAGUE) > Conceptual key (TERRORISM IS AN ILLNESS).

In this study, the analysis focuses only on the conceptualization of terrorism related to one lexical domain, fight. The second step of the approach, metaphor interpretation, aims at interpreting the metaphorical elements in relation to their contextual meaning in the discourse. This includes the social, historical, and geopolitical context in which the metaphor occurs. The last step, metaphor explanation, reveals the purpose of the speaker when using a specific metaphorical element. For constraint reasons of space, the analysis will discuss the most relevant examples.

\section{Analysis and results}

This section is twofold. First, I demonstrate that the notion of fight is predominantly used in Zapatero's discourse on terrorism. In order to do so, it presents overall findings in relation to the metaphorical elements (metaphorical expressions, metaphor keywords, conceptual metaphors, and conceptual keys) that conceptualize terrorism and aspects related to it. Second, it provides explicit evidence and examines in detail how the elements mentioned previously contribute to promote Zapatero's anti-terrorism political agenda.

Research has shown the use of bellicose metaphoric language in politics to frame social 
problems (Elwood, 1995; Rodríguez González, 1991; Thompson, 1996). Rodríguez González (1991: 104) indicates that terms such as guerra ('war'), armas ('weapon'), batalla ('battle'), and herida ('hurt') are often used in periodistic journals like Cambio 16 to talk about politics. Researchers have referred to this metaphoric language with different names: military metaphors, conflict metaphors, war metaphors, etc. As mentioned previously, I will refer to these metaphors as Fight Metaphors. This decision is based on the following factors: first, all metaphorical expressions belong to the source domain of fight; second, all metaphor keywords are related to the idea of fight within the context in which they occurred. Moreover, the most common metaphor keyword is the noun lucha. Third, the data shows that the notion of fight constitutes the pivotal node that simultaneously performs various discourse functions at several levels: cognitive, rhetorical, and ideological. Fight is Zapatero's political strategy to convey his political ideology. His fight is ideological and not physical. By drawing this distinction he is drawing a difference with the previous president José María Aznar who supported the war in Iraq, although many Spaniards went on strike demonstrating against it.

The analysis of the corpus shows that the lexical domain of fight includes 250 metaphorical expressions (Appendix A), and 53 metaphor keywords: 22 nouns, 30 verbs, and only one adjective (esgrimible). In addition to this, a total of 24 conceptual metaphors (Appendix B) were formulated, and three major conceptual keys were identified. All the metaphor keywords represent the action of opposing or resisting something. Thus, terrorism is conceptualized in terms of military strategies. The metaphor keywords are the following: abordar ('to board'), adversario ('adversary'), afrontar ('to face'), aislar ('to isolate'), amenaza ('to threaten'), aliarse ('to ally'), aportar ('to give'), arma ('weapon'), armazón ('shield'), arrodillarse ('to knee'), atacar ('to attack'), azote ('whip'), barbarie ('barbarism'), batalla ('battle'), cercar ('to corner'), coartada ('alibi'), combate ('combat'), combatir ('to combat'), conquista ('conquest'), conquistar ('to conquer'), dañar ('to hurt'), defender ('to defend'), defensa ('defense'), derrota ('defeat'), derrotar ('to defeat'), desafio ('challenge'), desgarrar ('to tear'), desterrar ('to exile'), destruir ('to destroy'), eliminar ('to eliminate'), enemigo ('enemy'), enfrentarse ('to face/confront'), esgrimir ('to fence/defend'), esgrimible ('defendable'), estrategia ('strategy'), forjar ('to force'), ganar ('to win'), golpear ('to hit'), golpe ('hit'), herir ('to hurt'), imponer ('to impose'), libertad ('freedom'), lucha ('fight'), luchar ('to fight'), manifestarse ('to demonstrate'), militante ('militant'), plegarse ('to bend'), prevenir (to prevent'), prisionero ('prisoner'), quebrar ('to break'), resistir ('to resist'), resistencia ('resistance'), vencer ('to win'), and victoria ('victory').

It should be noted that some of the metaphor keywords seem to be more central to the idea of fight than others. However, its contextual meaning made possible to group them under this domain. In this respect, they seem to be borderline cases that can belong to more than one source domain. This is the case of metaphor keywords such as herir, dañar, aislar, arrodillarse, azote, coartada, and forjar. Let us examine some cases. The verbs herir and dañar denote physical damage or pain. Therefore, they can be related to the source domain of fight, because both actions are consequences of a fight or a battle. However, they could also be related to the notion of body because physical pain is realized in a person. In this case, the metaphor keyword could be related to more than one source domains (fight and body). Also, the verb arrodillarse implies primarily a movement downwards of folding the knees. 
However, its contextual meaning reveals an association to the notion of fight. Arrodillarse is used to indicate the attitude of the Spanish Government in his fight against terrorism. The context indicates that the Spanish Government is depicted as a person that has and will never surrender to terrorism:

"Ningún Gobierno español se ha arrodillado frente al terror y ninguno se arrodillará". [No Spanish Government has knelt to terrorism, and never will do] (12/13/2004)

Coartada is another interesting example. This keyword is used to indicate that the notion of idea is portrayed metaphorically as an entity that has an alibi to justify assassination for the cause of terrorism. In this regard, political ideologies are metaphorically depicted as individuals that justify the action of killing others:

"Ninguna idea, por legítima que sea o parezca, puede servir de coartada para el asesinato o la barbarie. [No idea, as legitimate as it may seem, could serve as alibi for assasination or barbarity] $(9 / 15 / 2005)$

The data shows that the most frequent metaphor keyword is the noun la lucha, which appears 81 times. This keyword appears repeatedly as part of the following metaphorical expression, la luch a contra el terrorismo, which is the most dominant expression in the corpus. This metaphorical expression can be further realized as part of the following conceptual metaphor: TERRORISM IS A FIGHT. Its high frequency in the corpus reveals a significant aspect in the conceptualization of terrorism. This is, the most frequent aspect conceptualized by Zapatero is not terrorism/terrorists nor those who are against it/them, but rather on how to solve this social problem. This reveals his political intention of providing a solution to this long-term problem.

Although the most common keyword is a noun, the majority of the metaphor keywords are verbs (30). Verbs are actions per se and their contextual use is frequently associated with a call for action. On this basis, it should be noted that the etymological meaning of most of the verbs is related to physical action (atacar, luchar, combatir, conquistar, derrotar, defender, golpear, resistir, vencer, etc.). However, their contextual meaning never refers to a physical action but to a pacific, ideological, moral, and rational one. The most dominant verb metaphor keyword is combatir, which appears 20 times. As it occurs with lucha, combatir also appears as part of the following metaphorical expression: combatir el terrorismo. This expression can be conceptually represented as: TERRORISM IS A COMBAT. This conceptual metaphor is of political significance in Zapatero's discourse. It is intended to be a call of action to end up with terrorism, but not through physical violence. Finally, the only adjective metaphor keyword in the corpus, esgrimible, is used to emphasize any cause should be justified with the use of violence.

The data shows that the conceptualization of terrorism focuses mainly on three aspects: terrorism in itself, those who opposed to it, and how to solve this social problem. Let us analyze first the metaphorical conceptualization of terrorism. Within the conceptual framework of fight, terrorism is metaphorically depicted as an enemy: 
(1) El terrorismo es, sin duda alguna, un enemigo terrible. ${ }^{1}$ [Terrorism is, without any doubt, a terrible enemy] (11/04/2006)

Example (1) presents terrorism as a terrible enemy. The conceptual metaphor realized as follows: TERRORISM IS THE ENEMY. The metaphor keyword enemigo represents two aspects: First, terrorism is personified as the enemy. Zapatero portrays politics as a battleground. His battleground has two groups, those who are with him, and the enemies who are against him. Second, by describing terrorism as an enemy, terrorism has some implications. The main implication is that an enemy can be fought bravely and defeated; therefore, terrorism can be defeated. Another implication is that an enemy is a human being that can be identified and recognized, with a name and a physical image, like the real terrorists. Furthermore, Zapatero exploits the bellicose language to emphasize that the action of terrorism is characterized as cruel and violent through noun metaphor keywords such as la amenaza, el azote, and la barbarie:

(2) Definitivamente, y en términos europeos, hoy se ha aprendido que nadie está exento de la amenaza terrorista. [Definitely, in European terms, today we have learnt that nobody is exempt from the terrorist menace] $(12 / 21 / 2004)$

(3) España está del lado de Israel frente al terrible azote del terrorismo. [Spain is on Israel's side regarding the terrible whip of terrorism] (09/21/2004)

(4) $[. .$.$] al atentado terrorista que se ha producido en Egipto, a una nueva barbarie del$ terrorismo internacional. [to the terrorist attack carried out in Egypt, to a new barbarism of international terrorism (07/23/2005)

As it may happen in a fight, there are usually two groups involved. The two groups implied here are those who provoke terrorism, and those who defend themselves against it. The data indicates that certain actions are associated with terrorism. Others are associated with those who try to end it and are represented by the citizens of Spain and the Government. In this sense, the following verb metaphor keywords are always associated to terrorism: amenaza, destruir, eliminar, and golpear. It is also interesting to notice that verb metaphor keywords such as desterrar can be part of two source domains, the one of fight, but also of motion.

(5) Para evitar las guerras hay que desterrarlas, en primer lugar, de la mente y de los corazones. [In order to be avoided, wars need to be exiled, in first place, from the mind and from the heart $](06 / 23 / 2004)$

(6) Desterrar la hipocresía es también capital para obtener la victoria en la lucha contra el terror. [To exile hypocrisy is also essential to obtain the victory in the fight against the terror] $(03 / 10 / 2005)$

The metaphor keyword desterrar is used metaphorically to evoke the notion of exile. This 
lexical choice is particularly appealing because desterrar implies a movement; a forced removal of an individual from one place to another. The direct object of the verb desterrar does not refer to an individual, but to war and hypocrisy. Besides, the exile is not made from a country to another place, but from the mind and from the heart. Example (5) suggests that in order to avoid wars, we need to remove the idea of having a war from our minds as well as from our hearts. Zapatero emphasizes here once again the power of the mind in politics as well as his peaceful political ideology.

Contrasting with the negative representation of terrorism as enemy, Zapatero presents the positive notion of the hero and the winner that will end up with it: Madrid, as a metonymy that stands for the citizens of the capital of Spain, is also described as having the following features: courage, solidarity, and heroism.

(7) Ante el terror, Madrid ha dado ejemplo de coraje, de solidaridad y de heroísmo. Y con Madrid, toda España. [In the presence of terror, Madrid has been an example of courage, solidarity, and heroism. And with Madrid, all Spain] (04/16/2000)

In example (7), Madrid is also described as having the following features: courage, solidarity, and heroism. The conceptual metaphor can be realized as: MADRID IS A HERO. In fact, in the second part of the example, the idea of hero is extended to the whole country, Spain: SPAIN IS A HERO. In this respect, a conceptual key can be formulated as follows: SOCIETY IS A HERO. Features that define entities such as Spain, Spain's society, and Madrid are carefully and consciously selected by Zapatero. They all portray Spain with a positive connotation; this is, as a hero. This contrasts with the characterization of terrorism, which is depicted as a villain and as an enemy.

In addition to the positive image of Madrid, Spain, and society, Zapatero chooses to define himself metaphorically with a recurring linguistic choice: un militante. This noun denotes a different meaning than militar. Militant creates a symbolic contrast since its etymology clearly comes from the context of militia, in which people serve for a cause, but in an aggressive and physical manner. Zapatero portrays himself as the defender of democratic values:

(8) [...] voy a ser un militante para la defensa de los principios democráticos en la lucha contra el terrorismo, un militante activo. [I am going to be a militant for the defense of democratic principles in the fight against terrorism, an active militant] (07/16/2004)

In example (8), the term militante implies several aspects: to actively serve in a cause which is usually associated with war or militia; it implies discipline, commitment, and no fear. By describing himself as a militante, he portrays himself to the general public as an active person that serves to end terrorism pacifically. The cause he fights is terrorism. However, he fights it peacefully, rationally, and with dialogue; not with a war. Therefore, the field where he fights is not a battlefield, but a political one. Zapatero stated the following with respect to the war in Iraq: 
Dijimos también que la guerra era mucho más fácil de ganar que la paz. La paz es la tarea; una tarea que exige más valentía, más determinación y más heroísmo que la guerra. Por eso las tropas españolas regresaron de Iraq [We also said that war is much easier to win than peace. Peace is a task. A task that demands more boldness, more determination, and more heroism than war] $(09 / 21 / 2004)$

This extract shows his active militant attitude, which is for peace, and neither for war nor physical violence.

As mentioned previously, terrorism and those entities that are against it, form the two major focuses of the conceptualization. However, the aspect of terrorism that appears most dominant in Zapatero's discourse is how to solve the conflict. The data illustrates that Zapatero's rhetoric is bellicose in the sense that he often uses verbiage that evokes the notion of fight. This includes metaphor keywords such as lucha, luchar, batalla, combate, combatir, derrota, prisionero, etc. This can be exemplified with the following metaphorical instances:

(9) la batalla contra el terrorismo. [the battle against terrorism] (07/16/2004)

(10) la batalla de las mentalidades the battle of mentalities. (09/15/2005)

(11) nuestro combate contra el terrorismo. [our combat against terrorism] (03/10/2005)

(12) prisioneros del debate esencialista. [prisoners of the essentialist debate] (02/01/2007)

These metaphorical examples provide evidence for the following conceptualizations: TERRORISM IS A BATTLE, IDEOLOGY IS A BATTLE, TERRORISM IS A COMBAT, ESSENTIALIST DISUSSION IS A PRISON. Particularly noteworthy in Zapatero's discourse is that he does not use the term guerra to address terrorism. The phrase la guerra contra el terrorismo is never found in the data. This is because Zapatero does not believe in a physical war or violence to solve the problem, and he states this repeatedly and clearly in his political speeches:

"Creo firmemente que para combatir el terrorismo el camino no es la guerra convencional". [I firmly believe that conventional war is not the way to combat terrorism] (09/07/2004)

This conscious choice helps to create and enforce a stronger bond between himself and the general public that demonstrated and mobilized massively multiple times against the Iraq war. By doing this, he is also drawing a distinction with the previous president José María Aznar from the opposition party, who supported the war in Iraq. In addition, Zapatero also draws a distinction with previous American president George Bush. While the expression the war against terrorism characterized Bush's discourse, the fight against terrorism identifies Zapatero's political ideology. Beer and De Landtscheer (2004: 30) indicate that metaphors may suggest new solutions to long-standing political conflicts. In this way, the pervasiveness of Fight Metaphors in the corpus reveals that Zapatero's use of fight reveals a non-violent 
ideology, through a moral, peaceful, and rational action. His fight is a peaceful action against terrorism. Here are some metaphorical instances that illustrate his fight:

(13) [...] abordar una lucha inteligente, acertada y unitaria contra el terrorismo. [to undertake an intelligent, well-aimed, and unitary fight against terrorism] (07/16/2004)

In example (13), the adjectives that describe Zapatero's fight (inteligente, acertada, unitaria) indicate that the fight shows maturity, rationality, good judgment, and is based on a unanimous consensus on the public:

(14) La convicción de que es así, desde la legalidad, y sólo así, es cómo se gana el combate al terrorismo. [The conviction that it is like this, from legality, and only in this way, is how to win the combat with terrorism] (09/21/2004)

Example (14) emphasizes that the fight, portrayed in this case as a combat, will only be won legally. The metaphor keyword combate depicts the political ground as a battlefield again with terrorism as the cause of this battle. The difference with a physical battle is that the weapons used in this battle are not like the real ones, but they represent the democratic means like legality and laws. Thus, this metaphor highlights the idea that people that follow the democratic laws will win this fight.

(15) [...] esa unión (referring to the so called agreement Pacto por las Libertades y contra el Terrorismo) es una de las armas más eficaces para conseguir ese objetivo. [this union is one of the most efficient weapons to reach this goal] $(01 / 15 / 2007)$

Example (15) presents a metaphorical expression in which the union is portrayed metaphorically as one of the most efficient weapons. The conceptual metaphor that can be formulated here is: UNITY IS A WEAPON. Once again, this shows Zapatero's political way of fighting terrorism, not with real weapons, but with democratic ones. Zapatero's fight is a moral and democratic one because it has its foundation in moral and democratic values such as freedom, legality, and democracy.

(16) La lucha contra el terrorismo nos exige desarrollar un armazón moral, intelectual, jurídico y policial que fortalezca la legitimidad de nuestros esfuerzos. [The fight against terrorism demands us to develop a moral, intelectual, juridic, and police-like shield] $(03 / 10 / 2005)$

Example (16) presents an interesting metaphorical instance. The noun metaphor keyword armazón indicates the type of protection needed to fight against terrorism. This protection is expressed through the image of a shield, which is moral, intellectual, and juridic.

Zapatero portrays the fight against terrorism as a collective one. This can be seen in example (17) with the verbs tomamos and perdimos, which correspond to the second person plural (nosotros). Besides, the linguistic choice of colectivo shows that the fear is not the fear 
of an individual, but a collective fear. This highlights again that the fight is the fight of a common large group, that is, the citizens of Spain. This also helps to construct and maintain the sense of unity and community among citizens, but also the bond with the government:

(17) El día en que tomamos conciencia de nuestra fuerza y perdimos el miedo colectivo empezamos a ganar nuestra batalla. [The day we became aware of our strenght and lost our collective fear, we started to win our battle] $(12 / 13 / 2004)$

(18) En nuestro esfuerzo por ganar la batalla de las mentalidades. [In our effort to win the battle of the mentalities] $(09 / 15 / 2005)$

Zapatero describes the fight against terrorism as a battle that can be won, and the demonstrative adjective nuestra in example (17), and nuestro in (18), emphasize the bond with the general public. The noun mentalidad refers to the way of thinking that characterizes an individual, a society, or even a generation. Here the term mentalidades refers to different ways of thinking, that is, the ones that are in favor and against terrorism. This example shows clearly that the fight is not a physical or territorial one, but an ideological one. The following conceptual metaphor can be realized: POLITICAL IDEOLOGIES ARE BATTLES.

(19) Cada golpe nos ha reafirmado en nuestros valores. La memoria de las víctimas da sentido a nuestra resistencia frente al terror y redobla el valor de nuestra libertad. [Every hit has reasserted our values. The memory of the victims gives sense to our resistance to terror and redoubles the value of our freedom] $(12 / 13 / 2004)$

Example (19) includes metaphors that emphasize the boldness and the importance of moral values of the citizens of Spain. The metaphorical instance Cada golpe nos ha reafirmado en nuestros valores indicates the courageous attitude of the citizens after a terrorist attack. The contextual meaning of the keyword golpe refers to the March $11^{\text {th }}$ terrorist attack in Madrid. Zapatero highlights the idea that every terrorist attack instead of provoking fear in the citizens has the opposite effect. It has made citizens reaffirm their values and their attitudes. Zapatero's rhetoric strategy indicates that he hits back with his words. The notion of fight does not only indicate his political ideology, but it can also be implicitly perceived in his argumentative rhetoric, this is, the way he fights back with words in his political argumentations. Zapatero also emphasizes that it is the memory of the victims which reinforces Spain's citizens to strongly resist the menace of terror. The notion of resistance is again not a physical one but a psychological one. Zapatero emphasizes the power of the mind. He mentions how powerful the mind can be when used for the wrong reasons like terrorism, fanaticism, or extremism.

One final example in this section indicates that Zapatero does not draw a distinction in the way he conceptualizes national or international terrorism. Both types of terrorism are conceptualized in the same way since their ultimate goal is to kill and hurt people.

(20) [.... garantizar seguridad en la lucha contra el terrorismo, tanto nacional como internacional. [to guarantee security in the fight against terrorism, at a national and 
international level] $(01 / 10 / 2006)$

Example (20) indicates that terrorism, whether at national or international level, needs to be fought. By doing this, Zapatero emphasizes the idea of a common fight to end up with any kind of terrorism.

This section has shown that by exploring Zapatero's metaphorical bellicose language, it is possible to identify how he constructs the representation of terrorism at different levels: cognitive, rhetorical, and ideology. The data has indicated how Zapatero uses the metaphorical notion of the battlefield to present the political issue of terrorism. The notion of the battlefield allows him to represent terrorism in terms of military strategies, using terms such as atacar, amenaza, combate, combatir, lucha, luchar, adversario, enemigo, etc. In this sense, the weapons used in this battle are not real physical ones, but words, dialogue, legality, tolerance, etc. This battlefield scenario allows Zapatero to represent several aspects: first, the presentation of terrorism as a real and physical international menace that has killed and hurt people. Terrorism is conceptualized as a person who threatens, attacks, combats, fights, battles, provokes damage, and causes destruction and death; second, Zapatero presents the notion of the hero and the winner to emphasize democratic and moral values; third, this battlefield scenario allows him to promote his political ideology and his call for peaceful political action to solve this problem. Zapatero uses all this bellicose terminology in a metaphoric way to present his pro-peace ideology and his rejection to terrorism with moral values such as freedom, tolerance, respect, and democratic beliefs. Besides, his bellicose rhetoric used in his speeches supports his political ideology, and at the same time it also shows his way of fighting back with words, with dialogue, not killing people and causing casualties. What is also interesting in Zapatero's speeches is that he is very systematic in the use of some metaphorical expressions, and this is the case of the metaphorical expression la lucha contra el terrorismo, which appears 63 times out of 81 times of the metaphor keyword lucha.

\section{Conclusions}

The analysis of Zapatero's political speeches has shown that the notion of fight is predominantly used in his discourse on terrorism. Results of this investigation indicate that during a three-year period Zapatero consistently refers to aspects of terrorism invoking the concept of fight and uses the conceptual framework of fight to present how he envisions the problem of terrorism. This framework, full of bellicose language, evokes the battlefield scenario, where two fronts are being fought. The data shows that fight metaphors allow Zapatero to position the Government and citizens as the victims as well as heroes, fighting against terrorism and terrorists as the enemies. The metaphors reveal that Zapatero concentrates on three aspects: terrorism and terrorists, those who oppose terrorism (Government and citizens), and how to solve the problem of terrorism. These three aspects were conceptually represented as: TERRORISM IS THE ENEMY, SOCIETY IS A HERO, and TERRORISM IS A FIGHT. Interestingly, TERRORISM IS A FIGHT appeared to be the most dominant in his discourse, and it was mainly expressed as la lucha contra el terrorismo. This reveals his 
determination of solving the problem that has lasted for more than forty years in Spain. Of particular interest is to notice that while George Bush's discourse was characterized by the war against terrorism, the fight against terrorism is predominant in Zapatero's political rhetoric.

The arguments produced in the discussion show why Fight Metaphors are so prominent in Zapatero's discourse. They served indeed several functions in the discourse on terrorism: First, the rhetorical function, in which Zapatero's bellicose verbiage stimulates the citizens to be active participants. Second, the cognitive function through the conceptual system of fight. Fight Metaphors allow Zapatero to create a battlefield scenario to metaphorically present his political vision on terrorism. He presents terrorism as a common enemy both nationally and internationally. Third, the ideological function, through which Zapatero transmits his anti-terrorism political agenda and political ideology to the public. Despite his bellicose verbiage, the metaphorical language never contradicted his political ideology. In essence, his fight always aims to appease people in a peaceful way. For future research, it would be interesting to compare how left-wing and right-wing discourse conceptualize terrorism differently, and how this reflects each political ideology. In addition to this, it would be interesting to analyze how the notion of fight is used to conceptualize other social issues in Zapatero's discourse.

\section{Notes}

1. I would like to indicate that the text in bold corresponds to my interpretation of what I consider to be metaphoric.

\section{References}

Charteris-Black, Jonathan (2004): Corpus Approach to Critical Metaphor Analysis. New York: Palgrave MacMillan.

. (2005): Politicians and Rhetoric: The Persuasive Power of Metaphor. New York: Palgrave MacMillan.

Chilton, Paul (1996): Security Metaphor: Cold War Discourse from Containment to Common House. New York: Peter Lang.

Chilton, Paul and Ilyin, Mikhail (1993): "Metaphor in political discourse: The case of the "Common European House"'. Discourse and Society 4(1): 7-31.

Elwood, William (1995): "Declaring War on the Home Front: Metaphor, Presidents and the War on Drugs". Metaphor and Symbolic Activity 10 (2): 93-114.

Etkin, Jorge (1999): Metáfora y doble discurse politico. Buenos Aires: Eudeba.

Fairclough, Norman (1995): Critical Discourse Analysis: The Critical Study of Language. London /New York: Longman

Fernández Lagunilla, Marina (1999): La lengua en la comunicación política. La palabra del poder. Madrid: Arco Libros.

González García, José María (1998): Metáforas del poder. Madrid: Alianza Editorial.

Hellín, García María José (2008): Framing Terrorism via Metaphors: José Luis Rodríguez Zapatero (2004-2007). Unpublished Doctoral Dissertation. University of Minnesota, Minnesota. 
Hernández, María Lourdes (2004): “La metáfora política en la prensa venezolana”. Retrieved on 5 December 2005. Website: http://www.scielo.org.ve/pdf/op/v20n44/art4.pdf.

Howe, Nicholas (1988): "Metaphor in contemporary American political discourse". Metaphor and Symbolic Activity 3 (2): 87-104.

Johnson, Eric (2005): "War in the media". Metaphors, ideology and the formation of language policy. Bilingual Research Journal 29 (3): 621-640.

Lakoff, George (1993): “The Contemporary Theory of Metaphor". In A. Ortony, ed., Metaphor and Thought. 2nd edition. Cambridge: Cambridge University Press, 202-257.

. (2001): "Metaphors of Terror". In G. Lakoff, ed., Don't think of an elephant 2004. Chicago: University of Chicago Press, 52-68.

. (2003): "Metaphor and War Again: The Metaphor System Used to Justify War in the Gulf (Part I and II)". Retrieved on 5 May 2004. Website: http://www.alternet.org/story/15414 . (2004): "Framing the Debate: It's All GOP". Retrieved on 12 September 2004. Website: http://www.commondreams.org/views04/0912-20.htm

. (2005): "War on Terror, Rest in Peace". Retrieved on August 1st 2005. Website: http://www.alternet.org/story/23810

Lakoff, George and Johnson, Mark (1980): Metaphor We Live By. Chicago/London: The University Chicago Press.

Layton B. T. (2002): Metaphor and Political Persuasion. Unpublished Doctoral Dissertation. University of Southern California, Los Angeles, California.

Mio, Jeffery (1996): "Metaphor, Politics and Persuasion". In J. Mio and A. Katz, eds., Metaphor: Implications and Applications. New Jersey: Lawrence Erlbaum Associates Publishers, 127-146.

Moreno Lara, María Angeles (2004): La metáfora conceptual y el lenguaje político periodístico: configuración, interacciones y niveles de descripción. Unpublished Doctoral Dissertation. Universidad de la Rioja, Logroño, La Rioja.

Mussolf, Andreas (1998): "Metaphors and trains of thought. Spotting journey imagery in British and German political discourse". In S. Wright, L. Hanrais and J. Howorth, eds., Language, Politics and Society, 100-109.

. (2000): Mirror Images of Europe: Metaphors in the Public Debate about Europe in Britain and Germany. München: Iudiciyum.

. (2003): "Ideological functions of metaphor: The conceptual metaphors of health and illness in public discourse". In R Dirven, R. Frank and M. Pütz, eds., Cognitive Models in Language and Thought: Ideology, Metaphors and Meaning, Berlin/New York: Mouton de Gruyter, 327352.

. (2004): Metaphor and Political Discourse: Analogical Reasoning in Debates about Europe. New York: Palgrave MacMillan.

Pérez Rull, Juan Carmelo (2002): "Metáforas que expresan la intimidad emocional en el discurso español”. ORALIA 5:323-332.

Pujante, David and Morales López, Esperanza (1996-97): "Discurso político en la actualidad democrática española”. Discurso 21/22:39-75.

Pulgar Gutiérrez, Belén (2004): Victimas del terrorismo, 1968-2004. Madrid: Dykinson.

Reddy, Michael (1979): “The Conduit Metaphor". In A. Ortony, ed., Metaphor and Thought. Cambridge: Cambridge University Press, 164-201.

Rodríguez González, Félix (1991): Prensa y lenguaje político. Madrid: Fundamentos.

Rohrer, Tim (1991): “To plow the sea: Metaphors for regional peace in Latin America”. Metaphor and Symbolic Activity 6 (3): 163-181.

. (1995): "The metaphorical logic of (political) rape: the New Wor(1)d Order". Metaphor and 
Symbolic Activity 10 (2): 115-137.

Romaine, Suzanne (1996): "War and peace in the Global Greenhouse: Metaphors we die by". Metaphor and Symbolic Activity 11 (3): 175-194.

Salvador Caja, Gregorio (1987): "La lengua de los discursos del General Franco". In M. Alvar, coord., El lenguaje politico. Madrid: Fundación Ebert/Instituto de Cooperación Iberoamericana, 49-58.

Sandikcioglu, Esra (2000): "More metaphorical warfare in the Gulf: Orientalist frames in news coverage". In A. Barcelona, ed., Metaphor and Metonymy at the Crossroads: A Cognitive Perspective. Berlin/New York: Mouton de Gruyter, 299-320.

Santa Ana, Otto (1999): "Like an animal I was treated: anti-immigrant metaphor in US public discourse". Discourse and Society 10 (2): 191-224.

Thompson, Seth (1996): "Politics without metaphors is like a fish without water". In J. S. Mio and N. Katz. Mahwah, eds., Metaphor: Implications and Application. New Jersey: Lawrence Erlbaum Associates Inc., 185-201.

\section{APPENDIX A}

\section{Abordar}

[...] hemos abordado con especial interés diversos aspectos relacionados con la lucha (06/23/2004)

[...] abordar una lucha inteligente, acertada y unitaria contra el terrorismo (07/16/ 2004)

[...] abordar un proceso de paz (06/06/2006)

\section{Adversario}

[...] respetar las ideas del adversario $(03 / 1 / 2005)$

\section{Afrontar}

En esa misma ciudad de Madrid, que con tanta serenidad y entereza afrontó la tragedia de aquella barbarie terrorista $(03 / 22 / 2005)$

[...] cómo afrontar eficaz y conjuntamente el desafío del terrorismo (03/22/2005)

\section{Aislar}

Debemos reforzar los mecanismos de cooperación operativa para prevenir nuevos atentados, para aislar y cercar a las organizaciones terroristas $(03 / 10 / 2005)$

\footnotetext{
Amenaza

[...] prevenir la amenaza terrorista incidiendo en los factores y conflictos regionales que pueden exacerbarla $(06 / 15 / 2004)$

En el contexto en que hoy vivimos, en el contexto internacional y ante la amenaza de un terrorismo que se ha extendido $(07 / 16 / 2004)$

No necesito, por ello, recordaros que el terrorismo sigue siendo la peor amenaza para la seguridad colectiva de los ciudadanos (09/24/2004)

Es verdad que nadie puede garantizar el fin de la amenaza terrorista $(12 / 13 / 2004)$

Son actuaciones para corregir cualquier desprotección frente a la amenaza del terrorismo islamista $(12 / 13 / 2004)$

[...] el terrorismo supone una amenaza para la totalidad de los Estados miembros (12/21/2004)

[...] por ello, una larga experiencia sobre los instrumentos con que debe dotarse un Estado democrático para hacer frente a esta amenaza colectiva. (12/21/2004)
} 
Definitivamente, y en términos europeos, hoy se ha aprendido que nadie está exento de la amenaza terrorista $(12 / 21 / 2004)$

Espero que sus palabras generen el impulso necesario para completar y consolidar la legalidad internacional contra esta amenaza común $(03 / 10 / 2005)$

Somos hoy especialmente conscientes de la amenaza del terrorismo (03/22/2005)

[...] el terrorismo se cierne como una grave amenaza de nuestro tiempo para la seguridad y la paz $(09 / 15 / 2005)$

\section{Aliarse}

[...] alían voces predicando el culto y la exacerbación de la diferencia y el desprecio al otro $(03 / 22 / 2005)$

\section{Aportar}

[...] la reacción generosa de ciudadanos que, desde Madrid y desde todas las latitudes de España, aportaron su sangre y su aliento a las víctimas (12/13/2004)

\section{Arma}

[...] (la firma del Pacto por las Libertades y contra el Terrorismo) esa unión es una de las armas más eficaces para conseguir ese objetivo $(01 / 15 / 2007)$

\section{Armazón}

La lucha contra el terrorismo nos exige desarrollar un armazón moral, intelectual, jurídico y policial que fortalezca la legitimidad de nuestros esfuerzos $(03 / 10 / 2005)$

\section{Arrodillarse}

Ningún Gobierno español se ha arrodillado frente al terror y ninguno se arrodillará ( 2 times in $12 / 13 / 2004)$

\section{Atacar}

[...] atacando en paralelo las causas subyacentes que alimentan el fanatismo y dan alas a los terroristas $(09 / 07 / 2004)$

\section{Ataque}

Las víctimas del terrorismo sufren en su carne un ataque dirigido contra la sociedad en su conjunto $(03 / 10 / 2005)$

\section{Azote}

España está del lado de Israel frente al terrible azote del terrorismo [...] (09/21/2004)

[...] los ciudadanos inmigrantes, que han sufrido en carne propia el azote del terror $(01 / 15 / 2007)$

[...] manifestaron su resolución de preservar a las generaciones futuras del azote de la guerra $(9 / 21 / 2005)$

\section{Barbarie}

Quería, en primer lugar, hacer referencia al atentado terrorista que se ha producido en Egipto, a una nueva barbarie del terrorismo internacional, que ha costado la vida a decenas de personas inocentes $(07 / 23 / 2005)$ 


\section{Batalla}

Luchar contra el terrorismo y hacer de la batalla contra el terrorismo un gran objetivo colectivo $(07 / 16 / 2004)$

El día en que tomamos conciencia de nuestra fuerza y perdimos el miedo colectivo, ese día empezamos a ganar nuestra batalla. (12/13/2004)

No basta con ganar algunas batallas (09/15/2005)

En nuestro esfuerzo por ganar la batalla de las mentalidades $(09 / 15 / 2005)$

Los españoles saben que ésta es una batalla dura (01/04/2007)

\section{Cercar}

Debemos reforzar los mecanismos de cooperación operativa para prevenir nuevos atentados, para aislar y cercar a las organizaciones terroristas $(03 / 10 / 2005)$

\section{Coartada}

Ninguna idea, por legítima que sea o parezca, puede servir de coartada para el asesinato o la barbarie $(9 / 15 / 2005)$

\section{Combate}

[...] las fuerzas políticas han podido caer en la tentación de que [el terrorismo sea un elemento de combate entre partidos] $(07 / 16 / 2004)$

[...] ni una práctica democrática se puede alterar porque estemos en el combate contra el terrorismo $(07 / 16 / 2004)$

Seguiremos nuestro combate contra el terrorismo, (09/21/2004)

La convicción de que es así, desde la legalidad, y sólo así, cómo se gana el combate al terrorismo $(09 / 21 / 2004)$

Los españoles deben saber que en este combate no estamos solos (12/13/2004)

[...] el combate al terrorismo internacional, amenaza hoy de primer orden que debemos afrontar unidos y con gran determinación $(01 / 25 / 2005)$

$[\ldots]$ nuestro combate contra el terrorismo $(03 / 10 / 2005)$

Con su dilatada y dolorosa experiencia de más de treinta años de firme combate contra el terrorismo $[\ldots](9 / 15 / 2005)$

\section{Combatir}

[...] combatiré toda forma de xenofobia $(04 / 16 / 2004)$

[...] Estamos convencidos de que la vía seguida hasta ahora no es la mejor, ni para combatir el terrorismo internacional $(04 / 27 / 2004)$

[...] los medios para combatir sus fuentes de financiación (del terrorismo) $(06 / 15 / 2004)$

[...] para combatirla (la amenaza terrorista) mediante el fortalecimiento de las capacidades operativas y legislativas $(06 / 15$ / 2004)

[...] me parecen fundamentales a la hora de combatir el terrorismo $(07 / 16 / 2004)$

$[\ldots]$ combatir y de vencer al terrorismo es la afirmación democrática $(07 / 16 / 2004)$

Creo firmemente que para combatir el terrorismo el camino no es la guerra convencional

$(09 / 07 / 2004)$.

[...] se deben conocer sus raíces; se puede y se debe pensar racionalmente cómo se produce y cómo crece para combatirlo racionalmente $(09 / 21 / 2004)$ 
El 11 de marzo se hizo cruelmente presente en Madrid. Para estar en condiciones de combatirlo resulta imprescindible perfeccionar nuestros servicios de información y estar muy atentos, tanto a sus focos locales, como a su movilidad internacional (09/24/2004)

Así hicieron hace un año, al igual que vienen combatiendo el terrorismo desde hace treinta años $(03 / 10 / 2005)$

Coincidimos en que la cooperación internacional es necesaria para combatir lacras mundiales como el terrorismo y el narcotráfico $(03 / 31 / 2005)$

[...] casi todos ellos dedicados también a combatir el terrorismo internacional (05/11/2005)

Es imprescindible que estemos unidos para combatirlo (09/15/2005)

En nuestro esfuerzo por ganar la batalla de las mentalidades, no sólo hay que incrementar la asistencia técnica a los Estados para que puedan combatir el terrorismo en su propio territorio (09/15/2005) La eficacia en la prevención y la provisión de más medios de todo tipo para combatir el terrorismo han dado continuos frutos, como recientemente se ha podido corroborar (10/06/2005)

Debemos desmentir a los unos y combatir a los otros (12/08/2006)

Muchos de ellos me han manifestado apoyo para combatir la violencia (01/07/2007)

$[\ldots]$ combatir en los hechos la locura terrorista $(01 / 15 / 2005)$

[...] combatir el terrorismo $(01 / 15 / 2007)$

[...] el Gobierno expresa, una vez más, su máxima firmeza en combatir y perseguir la violencia y el terror $(01 / 15 / 2007)$

\section{Conquista}

$[\ldots]$ hoy derrotar al terrorismo es una gran conquista $(07 / 16 / 2004)$

El hombre ha logrado conquistas más difíciles en su historia y lo ha hecho cuando la inmensa humanidad que llevamos dentro se ha puesto al servicio de las causas más nobles (03/10/2005)

\section{Conquistar}

Conquistamos pacíficamente nuestras libertades (11/13/2006)

\section{Defender}

[...] defender a España (04/27/2004)

Frente al terrorismo internacional todos somos víctimas potenciales y, por ello, todos debemos aportar los medios y la cooperación imprescindible para defendernos de ellos (12/13/2004)

[...] establecer un gran acuerdo entre nosotros para defendernos del nuevo terrorismo internacional que tan cruelmente nos ha herido (12/13/2004)

Sólo tengo un empeño tan imperioso como proteger la vida de los españoles: defender nuestra libertad y (defender) nuestro marco democrático de convivencia ( 2 times in 12/13/2004)

[...] convicciones que defienden la legalidad internacional, la organización de Naciones Unidas y la lealtad en [la relación entre socios y aliados $(04 / 27 / 2004)$

[...] ¿para defender la democracia y el Estado de Derecho frente a las agresiones terroristas podemos poner en cuestión los propios valores que defendemos ( 2 times in 09/15/2005)

[...] pueden defender su visión de la justicia internacional por vías democráticas $(9 / 15 / 2005)$

[...] defender los valores democráticos, los valores constitucionales, la legalidad, el Estado de Derecho $(06 / 06 / 2006)$

[...] defendiendo los valores democráticos/los valores constitucionales ( 2 times in 06/29/2006) 


\section{Defensa}

En definitiva, la afirmación de los mejores valores, de defensa de los derechos humanos (07/16/2004)

[...] de defensa de la democracia /de la libertad (2 times in 07/16/2004)

[...] y de defensa de la solidaridad es el camino más contundente para luchar contra el terrorismo $(07 / 16 / 2004)$

Así lo exige el respeto profundo a las víctimas del terrorismo, así lo exige la defensa de la democracia, así lo exige la pervivencia de nuestro sistema de convivencia (12/13/2004)

Y yo lo que puedo decir es que voy a ser un militante para la defensa de los principios democráticos en la lucha contra el terrorismo, un militante activo (07/16/2004)

En todo caso, la defensa de nuestros ciudadanos y de nuestros valores no puede llevarse a cabo con un único instrumento, por poderoso que sea $(9 / 15 / 2005)$

[...] firmeza y unidad de los ciudadanos en defensa de las libertades, de los derechos fundamentales

y de los valores, reglas e instituciones de la democracia (01/15/2007)

\section{Derrota}

La democracia es la derrota del terrorismo $(03 / 10 / 2005)$

[...] nos enseñaron el camino para la derrota del terrorismo, la democracia, la fuerza de los valores $(03 / 10 / 2005)$

Compartimos el mejor y más valioso instrumento para la derrota del terror y de la violencia $(03 / 31 / 2005)$

La unidad de los demócratas, la acción eficaz de las fuerzas de policía, los servicios de inteligencia y los sistemas judiciales y la cooperación internacional son los mejores instrumentos para conseguir la derrota total del terrorismo $(07 / 07 / 2005)$

\section{Derrotar}

$[\ldots]$ hoy derrotar al terrorismo es una gran conquista $(07 / 16 / 2004)$

[...] un gran consenso social y ciudadano en el camino para derrotar al terrorismo (07/16/2004)

[...] seremos capaces de encontrar respuestas y soluciones democráticas para derrotar al terrorismo $(07 / 16 / 2004)$

[...] derrotemos a esta lacra que reiteradamente está asolando a ciudades, llevándose por delante vidas inocentes, sin la más mínima explicación (07/23/2005).

Para derrotarlo totalmente debemos entender cuáles son las condiciones que generan el extremismo y su transformación en estrategia del terror $(9 / 15 / 2005)$

Para derrotar al terrorismo y al extremismo debemos trabajar conjuntamente con el mundo musulmán, igualmente amenazado $(9 / 15 / 2006)$

[...] lograremos derrotar el terrorismo $(01 / 15 / 2007)$

\section{Desafio}

[...] el desafío del terrorismo $(03 / 22 / 2005)$

\section{Desgarrar}

[...] los conflictos que desgarran a muchos pueblos $(02 / 33 / 2005)$

\section{Desterrar}

Para evitar las guerras hay que desterrarlas, en primer lugar, de la mente y de los corazones ( 2 times in $06 / 23 / 2004$ ) 
Desterrar la hipocresía es también capital para obtener la victoria en la lucha contra el terror $(03 / 10 / 2005)$

\section{Eliminar}

[...] eliminar sus convicciones $(04 / 16 / 2004)$

\section{Enemigo}

El terrorismo es, sin duda alguna, un enemigo terrible (11/04/2006)

\section{Enfrentarse}

Tenemos que enfrentarnos al mismo con firmeza, pero también con racionalidad, evitando cometer errores que lo alimenten antes que debilitarlo (09/30/2004)

[...] los mecanismos con los que enfrentarnos al reto y al chantaje que se nos plantea (2 times in $01 / 15 / 2007)$

[... Los terroristas deben saber que se enfrentan a la voluntad de los demócratas (01/15/2007)

\section{Esgrimir}

[..] no demos ninguna oportunidad a que los terroristas, a que los violentos, a que los fanáticos, esgriman el hambre, la desesperanza, el arrinconamiento de los pueblos y la perspectiva de un futuro sin ningún norte y sin ningún horizonte para tantos seres humanos(07/16/2004)

La abrumadora mayoría del pueblo español se manifestó en contra de una guerra. No nos convencieron las razones que esgrimían quienes la promovieron (09/21/2004)

\section{Esgrimible}

Ninguna causa es esgrimible para ni siquiera entender ni comprender lo que representa el terrorismo $(07 / 16 / 2004)$

\section{Estrategia}

[...] a una reunión en la que (...) se defina una estrategia común $(04 / 16 / 2004)$

[...] la estrategia en la lucha internacional contra el terrorismo $(04 / 16 / 2004)$

En las doce reuniones que hasta ahora se han mantenido hemos logrado ponernos de acuerdo los dos grandes partidos nacionales para mantener una estrategia común contra el terrorismo (12/13/2004) [...] el apoyo a la estrategia del terror $(03 / 10 / 2005)$

[...] la mejor, la única, estrategia para aislar y derrotar al terrorismo estriba en el respeto a los derechos humanos, el impulso de la justicia social, la promoción de la democracia y la primacía del Estado de Derecho (03/10/2005)

Mi Gobierno apoya sin ambages la estrategia amplia de lucha contra el terrorismo presentada por el Secretario General Kofi Annan (9/15/2005)

[...] las condiciones que generan el extremismo y su transformación en estrategia del terror $(9 / 15 / 2005)$

En línea con las recomendaciones de la Proposición no de Ley, se ha endosado la estrategia contra esta lacra enunciada por el Secretario General en Madrid (9/21/2005)

[...] la estrategia contra quienes han protagonizado, durante tantos años, sin duda alguna, lo peor de nuestra historia colectiva reciente $(01 / 10 / 2006)$

No especulemos, pues, sobre cuál pueda ser su estrategia (la de ETA) (01/15/2007)

[..] los mecanismos de la estrategia antiterrorista (01/17/2007) 


\section{Forjar}

$[\ldots]$ a quienes forjan esos valores $(06 / 24 / 2004)$

\section{Ganar}

Dijimos también que la guerra era mucho más fácil de ganar que la paz (09/21/2004)

La convicción de que es así, desde la legalidad, y sólo así, cómo se gana el combate al terrorismo $(09 / 21 / 2004)$

El día en que tomamos conciencia de nuestra fuerza y perdimos el miedo colectivo, ese día empezamos a ganar nuestra batalla. $(12 / 13 / 2004)$

\section{Golpear}

[...] cooperación contra el (terrorismo) que nos ha golpeado durante cuarenta años (04/16/2004)

[...] el (terrorismo) que nos ha golpeado durante cuarenta años $(04 / 16 / 2004)$

[...] También conocemos el terrorismo, que nos lleva golpeando más de treinta años con mil vidas humanas perdidas $(09 / 21 / 2004)$

[...] los terroristas golpearon en el país más estéril de la tierra para sus ambiciones, a los ciudadanos del mundo más vacunados frente a sus métodos (12/13/2004)

El terror ha golpeado a nuestra patria de Norte a Sur y de Este a Oeste y no ha dispensado a ninguna edad ni a profesión alguna. Y nos hemos mantenido firmes contra él (12/13/2004)

El atentado que nos golpeó el 11 de marzo de 2004 a todos los españoles y que se cobró la vida de 192 seres humanos fue obra del terrorismo islamista $(12 / 13 / 2004)$

[...] que nos golpea desde hace más de treinta años $(06 / 04 / 2005)$

[...] cuando sufrimos el más duro golpe del terrorismo, los españoles, tantas veces golpeados por el terrorismo $(11 / 13 / 2007)$

\section{Golpe}

Los sucesivos golpes que ha sufrido ETA en los últimos meses confirman, con la fuerza de los hechos, lo que les digo $(12 / 13 / 2004)$

\section{Imponer}

[...] lamentablemente siempre habrá fanáticos dispuestos a asesinar para imponer su locura por la fuerza, dispuestos a extender la semilla del mal (09/21/2004)

\section{Libertad}

Claro que sus bombas tuvieron un efecto, sobre la carne y el acero, no sobre nuestra libertad, no sobre nuestro espíritu $(12 / 13 / 2004)$

\section{Lucha}

La lucha contra el terrorismo ( 2 times in $04 / 16 / 2004 ; 05 / 11 / 2004 ; 07 / 06 / 2004 ; 4$ times $07 / 16 / 2004$; $12 / 21 / 2004 ; 03 / 01 / 2005 ; 03 / 05 / 2005$; 2 times in $02 / 11 / 2005 ; 09 / 15 / 2005 ; 3$ times in 06/06/2006; $11 / 04 / 2006 ; 01 / 17 / 2007 ; 01 / 15 / 2007$ )

[...] la lucha sin cuartel contra el terrorismo/ contra cualquier terrorismo/ contra todo terrorismo (3 times in $04 / 16 / 2004)$

[...] una lucha en la que emplearemos todos los recursos de los que pueda dotarse una sociedad democrática $(04 / 16 / 2004)$.

[...] compromiso prioritario en la lucha contra el terrorismo $(04 / 16 / 2004)$

$[\ldots]$ compromiso en la lucha contra el terrorismo (04/16/2004) 
[...] la estrategia en la lucha internacional contra el terrorismo (04/16/2004)

[...] la lucha internacional contra el terrorismo $(04 / 27 / 2004)$

[...] España va a reforzar su compromiso en la lucha contra el terrorismo internacional $(04 / 27 / 2004)$

[...] la lucha contra el terrorismo en Iraq y en cualquier otra parte del mundo (04/27/ 2004)

$[\ldots]$ todos cuantos comparten esa lucha común $(04 / 27 / 2004)$

Dije, en fin, que la lucha contra el terrorismo constituiría la prioridad absoluta de mi Gobierno, que consideraba imprescindible para ello el fomento de la unidad de los demócratas [...] (05/11/2004)

También con México debemos felicitarnos de la cooperación alcanzada en materia de lucha contra el terrorismo $(05 / 27 / 2004)$

[...] la erradicación de la pobreza o la lucha contra el terrorismo $(05 / 28 / 2004)$

[...] hará especial hincapié en la lucha contra el terrorismo (06/ $15 / 2004)$

$[\ldots]$ intercambio de información para la lucha contra el terrorismo $(06 / 15 / 2004)$

En esta lucha hasta ahora se ha progresado mucho en el terreno legislativo, ahora hay que avanzar en el campo de la operatividad $(06 / 15 / 2004)$

[...] la lucha contra el terrorismo y la delincuencia organizada $(06 / 15$ / 2004)

En particular, hemos abordado con especial interés diversos aspectos relacionados con la lucha contra el terrorismo en la Unión Europea (06/23/ 2004)

La "Declaración sobre la lucha contra el terrorismo (06/23/ 2004)

[...] los valores en la lucha contra el terrorismo (06/24/2004)

$[\ldots]$ lucha por la paz y seguridad internacional $(07 / 06 / 2004)$

[...] la lucha contra el terrorismo no debe circunscribirse exclusivamente a la lucha militar y

policial contra las organizaciones terroristas $(07 / 06 / 2004)$

[...] la lucha de la Comunidad Internacional contra el terrorismo (07/06/2004)

[...] abordar una lucha inteligente, acertada y unitaria contra el terrorismo (07/16/2004)

$[\ldots]$ se está dando un paso atrás en la lucha contra el terrorismo $(07 / 16 / 2004)$

Ésa es la lección más importante que una sociedad ha dado en la lucha contra el terrorismo (07/16/ 2004)

La lucha contra el terrorismo y la criminalidad es una de las prioridades de este Gobierno, porque lo es de toda la sociedad española (09/17/2004)

[...] la estricta observancia de los derechos humanos en la lucha contra el terrorismo y la delincuencia $(09 / 21 / 2004)$

[...] en el área de la policía científica y de la inteligencia en la lucha contra el terrorismo y el crimen $(09 / 24 / 2004)$

La lucha contra el terrorismo de ETA no ha acabado y tenemos que mantener una alerta continua para prevenir sus golpes $(09 / 24 / 2004)$

Quiero comenzar afirmando que toda mi actividad política, antes y después de las últimas elecciones generales, ha estado inspirada por una idea fija: la lucha antiterrorista debe ser en España la prioridad absoluta de toda acción de gobierno (12/13/2004)

La lucha contra el terrorismo internacional constituye, cómo no, una preocupación prioritaria y nos mantenemos y nos mantendremos firmes contra esta lacra (09/30/2004)

[...] el más eficaz instrumento de lucha antiterrorista es la adopción de medidas preventivas, de robustecimiento de la seguridad ciudadana $(12 / 21 / 2004)$

La prevención y lucha contra el terrorismo internacional requieren, lo he dicho ya, la sustracción de la política antiterrorista del debate partidista y su consideración como política de Estado (12/13/2004) [...] a la mejora de la protección frente a ese tipo de terrorismo y a la necesidad de ampliar la base ciudadana de apoyo de la lucha antiterrorista dentro y fuera de nuestras fronteras (12/13/2004) 
Son los mismos ejes de la lucha antiterrorista en la que está empeñado mi Gobierno tal y como los expuse en el discurso de investidura (12/13/2004)

Nuestra lucha frente al terror sí lo tiene, sí posee sentido (12/13/2004)

Ha dado a lo largo de años resultados excelentes en la lucha contra ETA (12/13/2004)

Ahora, a la colaboración en la lucha contra ETA, hemos añadido la lucha contra el terrorismo internacional $(12 / 13 / 2004)$

Y yo lo que puedo decir es que voy a ser un militante para la defensa de los principios democráticos en la lucha contra el terrorismo, un militante activo (07/16/2004)

[...] la lucha contra la delincuencia internacional organizada, contra el narcotráfico y el terrorismo $(01 / 11 / 2005)$

La lucha contra el terrorismo nos exige desarrollar un armazón moral, intelectual, jurídico y policial que fortalezca la legitimidad de nuestros esfuerzos (03/10/2005)

Este consenso debe asentarse sobre los pilares del multilateralismo efectivo, la cooperación internacional y la defensa de la legalidad y los derechos humanos, lo que, además, hará la lucha mucho más eficaz $(03 / 10 / 05)$

Debemos, asimismo, reforzar el marco institucional de las Naciones Unidas para que puedan liderar esa lucha más eficazmente $(03 / 10 / 2005)$

Desterrar la hipocresía es también capital para obtener la victoria en la lucha contra el terror $(03 / 10 / 2005)$

La lucha por la libertad, la justicia y la eliminación de la pobreza no admite otras vías que el reforzamiento de la institucionalidad democrática y de la cohesión social $(03 / 31 / 2005)$

[...] los caminos de la política y de la lucha contra el terrorismo nunca se cruzasen $(05 / 11 / 2005)$

Cuando fui líder de la oposición, di mi pleno apoyo al Gobierno en la lucha antiterrorista y los ciudadanos así lo valoraron $(05 / 11 / 2005)$

[...] la lucha contra el delito, en la lucha contra las mafias y en la lucha contra el terror (06/04/2005) También estáis participando activamente, como desde hace demasiado tiempo, en la lucha contra el terrorismo $(06 / 04 / 2005)$

[...] (la lucha) contra el nuevo terrorismo internacional que tan brutalmente nos golpeó hace algo más de un año $(06 / 04 / 2005)$

[...] (la lucha) contra el terrorismo viejo, inútil, sanguinario, sin sentido (06/04/2005)

Existe coincidencia universal en valorar la lucha contra el extremismo y su criatura, el terrorismo $(9 / 15 / 2005)$

Existe coincidencia universal en valorar la lucha contra el extremismo y su criatura, el terrorismo $(9 / 15 / 2005)$

La creación del Comité de la Lucha contra el Terrorismo (CTC) (09/15/2005)

Mi Gobierno apoya sin ambages la estrategia amplia de lucha contra el terrorismo presentada por el Secretario General Kofi Annan (9/15/2005)

$[\ldots]$ la condena firme y la lucha contra el terrorismo(9/21/2005)

España subrayó la prioridad que concedemos a la lucha internacional contra el terrorismo, así como la voluntad de reforzar y consolidar su marco jurídico (9/21/2005)

Así sucede también en el ámbito de la lucha contra el terrorismo (10/2/2005)

[....] garantizar seguridad en la lucha contra el terrorismo, tanto nacional como internacional $(01 / 10 / 2006)$

\section{Luchar}

La Unión se dota así de mecanismos más eficaces para luchar contra el terrorismo (06/23/2004) 
Cuando se cae en la tentación y la ciudadanía percibe que la unidad sincera, real, de luchar contra el terrorismo está en cuestión $(07 / 16 / 2004)$

[...] luchar contra el terrorismo (07/16/2004; 03/10/05)

[...] de defensa de la libertad y de defensa de la solidaridad es el camino más contundente para luchar contra el terrorismo $(07 / 16 / 2004)$

Luchar contra el terrorismo y hacer de la batalla contra el terrorismo un gran objetivo colectivo $(07 / 16 / 2004)$

[...] luchar eficazmente contra la financiación del terrorismo $(03 / 10 / 05)$

[...] desde el pasado año tenemos trescientos profesionales más luchando contra el terrorismo internacional $(05 / 11 / 2005)$

\section{Manifestarse}

Sabemos por experiencia que el inicio del fin de ETA, aunque todavía no esté cerrado, se produjo el día en que los ciudadanos salieron por millones a la calle a manifestarse contra el terror (12/13/2004)

\section{Militante}

Y yo lo que puedo decir es que voy a ser un militante para la defensa de los principios democráticos en la lucha contra el terrorismo $(07 / 16 / 2004)$

[...] un militante activo $(07 / 16 / 2004)$

\section{Plegarse}

Conociendo a nuestro pueblo, es inconcebible que alguien pueda imaginar que los ciudadanos españoles se plegaran a las supuestas intenciones de los terroristas $(12 / 13 / 2004)$

\section{Prevenir}

La lucha contra el terrorismo de ETA no ha acabado y tenemos que mantener una alerta continua para prevenir sus golpes $(09 / 24 / 2004)$

\section{Prisionero}

Para hacerlo tenemos que evitar caer prisioneros del debate esencialista y volcarnos hacia los problemas que tenemos colectivamente, hacia las necesidades y aspiraciones de los ciudadanos $(02 / 01 / 2007)$

\section{Quebrar}

La violencia quebró las vidas de nuestros hermanos, pero no la integridad y los principios de nuestro pueblo $(11 / 13 / 2006)$

\section{Resistir}

Resistiremos al terrorismo $(09 / 21 / 2004)$

\section{Resistencia}

Cada golpe nos ha reafirmado en nuestros valores. La memoria de las víctimas da sentido a nuestra resistencia frente al terror y redobla el valor de nuestra libertad. (12/13/2004)

\section{Sacudir}

Hace sólo unos días conmemoramos el primer aniversario de los terribles atentados que sacudieron Madrid el 11 de marzo de 2004 (03/22/2005) 


\section{Vencer}

[...] podemos vencer al terrorismo $(07 / 16 / 2004)$

[...] combatir y de vencer al terrorismo es la afirmación democrática $(07 / 16 / 2004)$

La idea central para vencer al terrorismo (07/16/2004)

[...] al terrorismo se le vencerá con firmeza, con unidad, con contundencia y con cooperación internacional en los ámbitos de la inteligencia, legislativo, judicial (07/16/2004)

Para vencer al terrorismo tenemos también que hacer un esfuerzo cabal de comprensión de la amenaza $(03 / 10 / 2005)$

Para vencer al terrorismo, la Comunidad Internacional debe forjar urgentemente un consenso político $(03 / 10 / 2005)$

Para vencer al terrorismo necesitamos también un consenso político y estratégico (9/15/2006)

\section{Victoria}

[...] obtener la victoria en la lucha contra el terror $(03 / 10 / 2005)$

[...] Sólo así crearemos el clima político necesario para nuestra definitiva victoria (9/15/2005)

[...] sólo una victoria de la sociedad occidental, sino la victoria compartida de todas las gentes de bien (2 times 9/15/2005)

\section{APPENDIX B}

\section{Conceptual metaphors:}

- ARGUMENT IS WAR

- terRorism is A PERSON THAT CAN BE CORNERED

- TERRORISM IS A THREAT

- DEMOCRACY IS A MORAL SHIELD

- TERRORISM IS AN ATTACK

- TERRORISM HAS AN ALIBI

- ideology is a batTle

- TERRORISM IS COMBAT

- TERRORISM IS DAMAGE

- TERRORISM IS A PERSON WHO CAN BE DEFEATED

- TERRORISM IS A PERSON WHO CAN BE FACED

- TERRORISM IS A STRATEGY

- TERRORISM IS A HIT

- TERRORISM IS A FIGHT

- TERRORISM IS A KILLER

- TERRORISM IS A PERSECUTOR

- MADRID IS A HERO

- SPAIN IS A HERO

- THE SOCIETY IS A HERO

- UNITY IS A WEAPON

- DEMOCRACY IS A WINNER

- MORAL PROTECTION IS A SHIELD

- POLITICAL IDEOLOGIES ARE ENEMIES

- POLITICAL IDEOLOGIES ARE BATTLES 